Brit. J. prev. soc. Med. (1975), 29, 239-248

\title{
Acceptability of the cytopipette in screening for cervical cancer
}

\author{
JANET CARRUTHERS1, J. M. G. WILSON1, JOCELYN CHAMBERLAIN1, O. A. N. \\ HUSAIN $^{2}$, D. G. H. PATEY 3 , N. D. RICHARDS 4 , A. PENNICOTT ${ }^{3}$, PAULINE ROGERS 1 , \\ ROSALIND CATLING 1 , T. W. MEADE 1 , J. SAUNDERS ${ }^{3}$ AND P. J. M. McEWAN ${ }^{4}$
}

Formerly of London School of Hygiene and Tropical Medicine ${ }^{1}$, St Stephen's Hospital, Fulham ${ }^{2}$, formerly of West Sussex County Council Health Department ${ }^{3}$, formerly of Centre for Social Research, University of Sussex ${ }^{4}$

\begin{abstract}
Carruthers, J., Wilson, J. M. G., Chamberlain, J., Husain, O. A. N., Patey, D. G. H., Richards, N. D., Pennicott, A., Rogers, P., Catling, R., Meade, T. W., Saunders, J., and McEwan, P. J. M. (1975). British Journal of Preventive and Social Medicine, 29, 239-248. Acceptability of the cytopipette in screening for cervical cancer. A randomized controlled trial was carried out in which the acceptability of screening for cervical carcinoma in situ by a postal 'do-it-yourself' method-the cytopipette-was compared with that of an invitation to attend a clinic or see a general practitioner for the conventional cervical scrape examination. In parallel with this, a sociological study of women who had been invited by both methods was undertaken in which information was obtained from responders and non-responders on attitudes to health care. The results show that, while the pipette was used by a greater proportion of women overall than the scrape examination, its acceptance by women most at risk of the disease is still not high. It is concluded that, taking into account the relative merits of the two methods as screening tests, as well as their acceptability and cost, the postal pipette may be useful in some circumstances, such as areas where clinical resources are limited, and as a second approach to women who have not taken up the offer of a scrape examination.
\end{abstract}

During the past two decades cervical cytology population screening has been increasingly practised in this country and elsewhere as a service for the prevention of carcinoma of the cervix. In spite of its widespread application, however, there has not yet been any wholly convincing evidence that mortality from this disease has been reduced as a result of screening although there is a suggestion that mortality rates may be falling faster than expected in areas where a high proportion of women have been screened (Kinlen and Doll, 1973). A possible reason why screening has so far failed to influence mortality substantially may be that the service is little used by the women most likely to develop the disease.

It has been recognized for a long time that cancer of the cervix, the incidence of which is highest in women in their fifth and sixth decades, is associated with high parity and low social class. Detailed aetiological studies such as those by Terriss and Oalmann (1960), Boyd and Doll (1964), and Aitken-Swan and Baird (1966) have established that the association with parity, and possibly to some extent with social group, are reflections of the fact that cervical cancer occurs more frequently in women who began sexual intercourse at an early age, who have had frequent intercourse (Rotkin, 1962), and who have had broken and multiple marriages, implying that some factor associated with coitus is of primary importance in its causation. Thus the women at highest risk, in whom the greatest yield of potentially treatable disease is likely to be found at screening, are women between the ages of 35 and 55 years, of low social 
class, who have married early, and who have had multiple partners. But it has been repeatedly shown-for example, in studies by Breslow and Hochstim (1964) and Kegeles (1967) in the United States and by the work of Wakefield and Sansom (1966) in this country-that such women are least likely to come forward for examination. Sansom, Wakefield, and Yule (1970) working in the Manchester region found that only $7 \%$ of women screened were over the age of 35 and in social classes IV and V, and the proportion of women of all ages in social classes IV and V in the screened group was $15 \%$ compared with $34 \%$ in the general population.

Because of their reluctance to attend clinics or see a doctor for examination, it was felt that the cytopipette, a 'do-it-yourself' method of obtaining cells for cytological examination, might be more acceptable to the high-risk women. The cytopipette, developed in Denmark by Davis and Kurz (1962), and Koch and Stakemann (1962), is a quick and simple method which can be used at any time or place convenient to the women. Although it is slightly less sensitive in detecting cervical carcinoma in situ than the conventional method of scraping cells from the cervical canal with a spatula (Husain, 1970), it has been suggested that it might be a useful means of approaching women who will not attend clinics (Anderson and Gunn, 1966). The present study was therefore designed to determine whether the cytopipette is more acceptable to high-risk women than the conventional method.

In parallel with this study, an investigation of a wide range of attitudes towards health services in general, and cervical cancer screening in particular, was undertaken on a sample of the population of women who were invited to be screened. While the general demographic characteristics of women who do not respond to the invitation for cytology have been described in some of the studies already mentioned, at the time of this study little was known about the attitudes and behaviour patterns of non-responders. Fink, Shapiro, and Lewison (1968) in New York questioned non-responders to breast cancer screening and found that, although apparently suffering more ill-health, they had negative attitudes to health services in general and used both curative and preventive services less than responders. Two more recent papers from Finland (Kauppinen et al., 1970; Vuori, Rimpela, and Gronroos, 1972) conclude that, in general, non-responders to cervical cytology have negative attitudes towards cancer, but that the non-responders are not a homogeneous group, some of them having valid reasons for non-response such as having been recently screened elsewhere (Allman, Chamberlain, $c$ and Harman, 1974) and others apparently being influenced more by factors associated with the 3 inconvenience of attending for screening than by응 their beliefs about the curability of cancer. It was $\Rightarrow$ felt that detailed information on the attitudes of $\frac{\text { ? }}{9}$ both responders and non-responders to the two screening methods in our survey could give potentially valuable leads as to methods of educating $\frac{\bar{s}}{\sigma}$ women to use the service.

\section{Methods}

\section{Comparative Study of Acceptability}

A randomized controlled design was chosen, the study group who were sent a cytopipette* (the 'pipette group') being compared with a controlo group who were sent an invitation to attend $a_{i u}^{+}$ clinic or see their general practitioner for a cervical scrape (the 'scrape group'). Because the pipette iso not regarded as a perfect substitute for the scrape method, all women who had been offered the pipette (regardless of whether or not they used $\mathbb{I}$ ) were offered the opportunity for a scrape test after the study was completed.

Statistical advice on sample size indicated thatra population of some 18000 women would be ade- $\overrightarrow{0}$ quate to test the acceptability of the alternat $\mathrm{e}^{\mathrm{c}} \mathrm{v}$ methods, and a town in west Sussex with surrounding rural area, was chosen. The Health Department of West Sussex County Council had already developed a computerized system for inviting women to be screened (Saunders and $\frac{\Phi}{\Omega}$ Snaith, 1969a) and were progressively extending $\overrightarrow{\vec{*}}$ this throughout the county. No systematic approach 3 had been made to women in the survey area and, during the study, health education publicity on theo value of cytology was deliberately avoided in order that acceptance rates would not be influencedo differentially in any way. The population of women on the appropriate electoral registers in February 1970 was used as the sampling frame. In order too minimize possible biases in acceptance arising from discussion of the different tests offered too women in the two groups, randomization was done? by area of residence rather than by individuato women. Urban and rural census enumeration districts were ordered according to size of populationo and randomly allocated to pipette or scrape invitation groups. The names and addresses of women electors in each district were then listed from the
electoral roll.

* Marketed by SKANDIALAB, Copenhagen 
Invitations to women in both groups were sent out at approximately monthly intervals. The women in the pipette group were sent an introductory letter followed two weeks later by the pipette package which contained a further letter, a questionnaire, the pipette itself with illustrated instructions on how to use it, and a prepaid envelope in which to return it to the laboratory. The questionnaire requested information about various demographic items and also about gynaecological history relevant to the interpretation of the specimen. If after nine weeks no reply had been received in the laboratory, a second pipette package was sent. Of those pipettes returned, some specimens were inadequate; in these cases another pipette was sent. If this proved unsatisfactory when returned to the laboratory, the woman was then offered a scrape examination.

The procedure for the scrape group followed that for the pipette group as closely as possible with regard to time relationships. Women in the scrape group were sent a letter of invitation which included an acceptance form on which the woman stated her preference for an examination at a Health Department clinic or (if she was over 35 years) by her general practitioner. If she returned the form, she was subsequently sent an appointment. If no reply had been received within nine weeks, a further invitation was sent. Before attending for examination the women filled in a questionnaire which asked for the same information as that in the pipette group.

All the specimens from women in both groups were examined in the same laboratory and the results were sent both to the woman and her general practitioner. If the specimen showed a suspicious or a positive result or minor disease such as trichomonas infection, the woman was asked to visit her general practitioner.

\section{Sociological Study}

Three sociological interview surveys (to be reported elsewhere) were undertaken on samples of women included in the main acceptability study. Trained female interviewers visited women at home and questioned them on a wide range of subjects relating to use of and attitudes towards health services, beliefs about preventive health practices, and attitudes towards cancer. A minimum of three unsuccessful visits at different times of day was required before classifying a woman as a nonresponder to interview. Sociological results presented in this paper are limited to general information from a $10 \%$ sample of the main study population who were interviewed after it was known whether or not they had accepted the screening invitation.

\section{RESULTS}

\section{Definition of Study Population}

Women whose names appeared on the electoral register but who had died before they had been invited to participate were excluded from analysis. However, it was not possible to exclude people who had moved away from the area before they could have received an invitation, because there was no means of reliably identifying all of them. The final study population consisted of 9417 women in the pipette group (4954 urban and 4463 rural), and 9682 women in the scrape group (5028 urban and 4654 rural). The sample chosen for the sociological study was stratified according to acceptor status 16 weeks after the first invitation and consisted of 892 women in the pipette group and 920 in the scrape group.

\section{Crude Response Rates}

Overall, $53 \%$ of women who had been invited to use the pipette responded, compared with $50 \%$ of women in the scrape group who wrote accepting the invitation to be screened. But nearly one-fifth of these women who accepted the scrape invitation failed to keep their appointment; thus the proportion of women actually tested was $53 \%$ in the pipette group and $41 \%$ in the scrape group, a difference statistically significant at the $0.1 \%$ level. This is illustrated in the Figure, which, in the histogram of overall response rates, represents in the hatched area the women who accepted the scrape invitation but then failed to attend. The Figure also shows that the difference between pipette and scrape response rates was greater in the rural area than the urban.

\section{Standardized Response Rates}

To ensure that the pipette and scrape groups were similar in their age and social class composition, estimates of these variables were made from census data. Unfortunately, the 1971 census, giving total population figures one year after the survey, could not be used because the boundaries of enumeration districts (on which the allocation into pipette and scrape groups was based) had been altered. Therefore, the $196610 \%$ sample census was used. In the rural area there was no significant difference between the pipette and scrape populations, but in the urban area the scrape population had significantly more people in the professional and managerial classes and fewer women over the age of 45 years. The response rates for the pipette group were re-calculated, standardized to the scrape population distributions first for age and secondly for social class. 

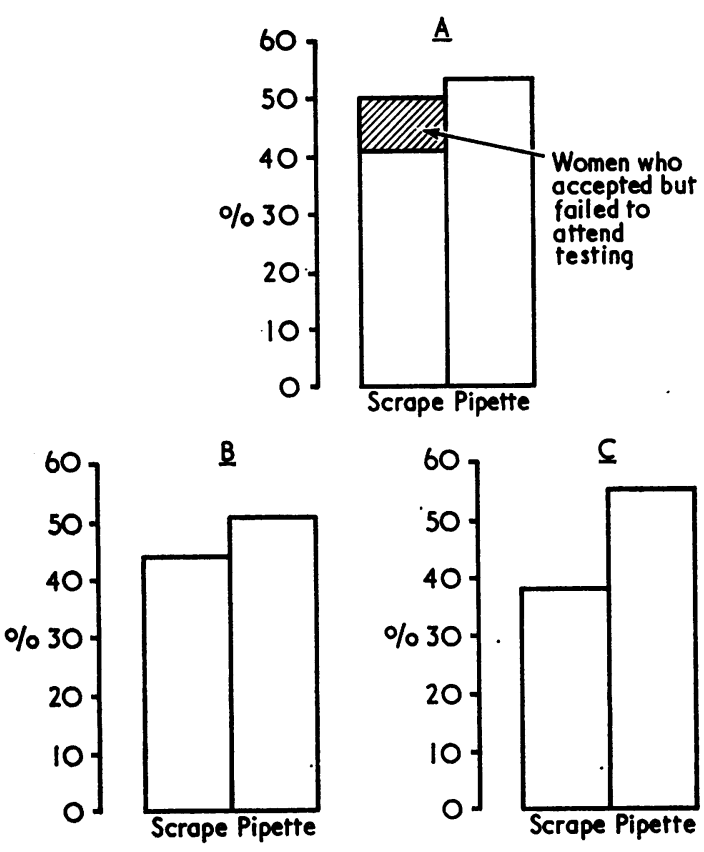

Fioure. Crude response rates. A Overall, B Urban, C Rural

The results are summarized in Table I from which it can be seen that the difference between pipette and scrape response in the urban area appears to be even greater than the crude rates would suggest.

TABLE I

RESPONSE RATES TO PIPETTE AND SCRAPE INVITATION

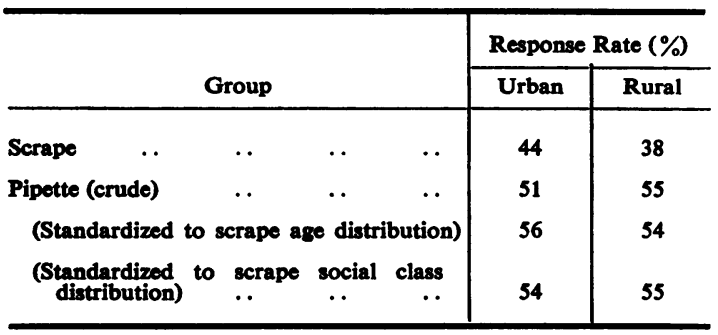

Response Rates within Age and Social Class GrouPs

Having established that more women overall responded to the pipette than to the scrape, this finding was examined further to determine if the high-risk women (those in middle age and social classes IV and V) responded more readily to thecs pipette. The denominator used for estimating within- -0 age and social class response was obtained from the 1966 sample census and hence is subject to sampling? error, and also represents the population as it had $=$ been four years before the survey. Therefore, $\stackrel{?}{9}$ these response rates should be interpreted with? some caution.

The age distributions, using the age-groups of $\tilde{\sigma}_{\overline{\mathbb{C}}}$ the female population given in the 1966 census reports, were obtained by applying the percentages distribution in the census sample in the relevant $\overrightarrow{0}$ districts to the pipette and scrape populations, $-\overrightarrow{-}$ and are shown in Table II together with the re-w sponses in each group. It seems that the pipette achieved a higher proportion of women screened? at every age, the difference being the greatest ini those under 30, but also worthy of note in women between 30 and 60 years.

Table III shows a similar estimated social classe distribution for women in the study. This wass

TABLE II ESTIMATED POPULATION AND RESPONSE IN DIFFEREN 윰

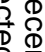

\begin{tabular}{|c|c|c|c|c|c|}
\hline \multicolumn{2}{|c|}{$\begin{array}{c}\text { Age Groups } \\
\text { (Years) }\end{array}$} & Method & $\begin{array}{c}\text { Estimated } \\
\text { Population }\end{array}$ & Responders & $\begin{array}{l}\text { Respons区 } \\
\text { Rate (\%) }\end{array}$ \\
\hline $18-29$ & . & $\begin{array}{l}\text { Pipette } \\
\text { Scrape }\end{array}$ & $\begin{array}{l}1789 \\
1936\end{array}$ & $\begin{array}{r}1221 \\
734\end{array}$ & $\begin{array}{l}68 \cdot 2 \\
37 \cdot 9\end{array}$ \\
\hline $30-44$ & . & $\begin{array}{l}\text { Pipette } \\
\text { Scrape }\end{array}$ & $\begin{array}{l}2448 \\
2808\end{array}$ & $\begin{array}{l}1558 \\
1509\end{array}$ & $\begin{array}{l}63 \cdot 6 \\
53 \cdot 7\end{array}$ \\
\hline $45-59$ & . & $\begin{array}{l}\text { Pipette } \\
\text { Serape }\end{array}$ & $\begin{array}{l}2354 \\
2227\end{array}$ & $\begin{array}{l}1433 \\
1162\end{array}$ & $\begin{array}{l}60 \cdot 9 \\
52 \cdot 2\end{array}$ \\
\hline $60+$ & . & $\begin{array}{l}\text { Pipette } \\
\text { Scrape }\end{array}$ & $\begin{array}{l}2919 \\
2711\end{array}$ & $\begin{array}{l}782 \\
579\end{array}$ & $\begin{array}{l}26 \cdot 8 \\
21 \cdot 4\end{array}$ \\
\hline
\end{tabular}

TABLE III ESTIMATED POPULATION AND RESPONSE IN DIFFERENT SOCLAL CLASSES*

\begin{tabular}{|c|c|c|c|c|c|c|}
\hline & & Method & $\begin{array}{c}\text { Estimated } \\
\text { Population }\end{array}$ & Responders & $\begin{array}{l}\text { Response } \\
\text { Rate (\%) }\end{array}$ & 옥 \\
\hline $\mathbf{I}$ & .. & $\begin{array}{l}\text { Pipette } \\
\text { Scrape }\end{array}$ & $\begin{array}{l}565 \\
775\end{array}$ & $\begin{array}{l}378 \\
345\end{array}$ & $\begin{array}{l}66 \cdot 9 \\
44 \cdot 5\end{array}$ & \\
\hline II & .. & $\begin{array}{l}\text { Pipette } \\
\text { Scrape }\end{array}$ & $\begin{array}{l}2072 \\
2130\end{array}$ & $\begin{array}{l}1353 \\
1136\end{array}$ & $\begin{array}{l}65 \cdot 3 \\
53 \cdot 3\end{array}$ & \\
\hline III & . & $\begin{array}{l}\text { Pipette } \\
\text { Scrape }\end{array}$ & $\begin{array}{l}4332 \\
4647\end{array}$ & $\begin{array}{l}2376 \\
1819\end{array}$ & $\begin{array}{l}54 \cdot 9 \\
39 \cdot 1\end{array}$ & \\
\hline IV & . & $\begin{array}{l}\text { Pipette } \\
\text { Scrape }\end{array}$ & $\begin{array}{l}1601 \\
1452\end{array}$ & $\begin{array}{l}439 \\
388\end{array}$ & $\begin{array}{l}27 \cdot 4 \\
26 \cdot 7\end{array}$ & \\
\hline $\mathbf{v}$ & . & $\begin{array}{l}\text { Pipette } \\
\text { Scrape }\end{array}$ & $\begin{array}{l}659 \\
484\end{array}$ & $\begin{array}{r}107 \\
82\end{array}$ & $\begin{array}{l}16 \cdot 2 \\
16 \cdot 9\end{array}$ & $\underset{0}{0}$ \\
\hline
\end{tabular}

*Excludes 314 pipette responders and 214 scrape responders whas gave insufficient information for determining social class 
derived from sample census data on economically active males in the relevant districts, and excludes those in whom social class was unclassified. The response rates indicate a considerably greater response to the pipette in social classes I, II, and III, but unfortunately it seems to have no advantage over the scrape among social classes IV and V. Although the pipette is more acceptable overall than the scrape, the response to it thus follows the same pattern as that to conventional cervical cytology, proving most acceptable to the women who are least likely to need it.

\section{Further Comparisons of Responders to EACH METHOD}

From the questionnaire completed by women who responded to each method, it was possible to compare the frequency in each group of a number of other characteristics related to risk of cervical cancer. In interpreting these findings, it should be remembered that the lack of information on nonresponders could mask possible differences between the groups which would occur if the base populations had different distributions of the variables concerned.

The questionnaire asked about marital status, parity, age at first marriage, and number of marriages. There were no obvious large differences in the distributions of these variables between women responding to pipette and to scrape. As an example the distribution of age at first marriage is shown in Table IV, subdivided into pipette and scrape groups in urban and rural areas. It can be seen that the responders in each category differ little in the proportion of women who married young. Similar pictures emerge when comparing other risk factors such as parity.

\section{TABLE IV}

PERCENTAGE DISTRIBUTION OF AGE AT FIRST MARRIAGE IN RESPONDERS TO PIPETTE AND SCRAPE

\begin{tabular}{|c|c|c|c|c|c|c|}
\hline \multirow{2}{*}{\multicolumn{3}{|c|}{$\begin{array}{l}\text { Age at First } \\
\text { Marriage } \\
\text { (Years) }\end{array}$}} & \multicolumn{2}{|c|}{ Urban } & \multicolumn{2}{|c|}{ Rural } \\
\hline & & & Pipette & Scrape & Pipette & Scrape \\
\hline $16-$ & . & . & $16 \cdot 6$ & $13 \cdot 1$ & $14 \cdot 0$ & $15 \cdot 8$ \\
\hline $20-$ & . & .. & $52 \cdot 0$ & $57 \cdot 4$ & $54 \cdot 8$ & $57 \cdot 4$ \\
\hline 25- & .. & .. & $22 \cdot 3$ & $21 \cdot 4$ & $21 \cdot 9$ & $21 \cdot 8$ \\
\hline $30-$ & .. & . & $6 \cdot 3$ & $5 \cdot 4$ & $4 \cdot 7$ & $4 \cdot 8$ \\
\hline $35-$ & . & .. & $1 \cdot 4$ & $1 \cdot 6$ & $1 \cdot 6$ & $1 \cdot 5$ \\
\hline $40+$ & . & . & $1 \cdot 3$ & $1 \cdot 1$ & $1 \cdot 2$ & 0.6 \\
\hline \multicolumn{3}{|c|}{ Sample size } & 2206 & 2018 & 2163 & 1581 \\
\hline
\end{tabular}

Some of the characteristics examined are not independent of each other-for example, parity is to some extent determined by age and by age at marriage. Certain variables were, therefore, standardized for others to see if the crude distributions might be concealing differences in the characteristics of responders in each group. The base population taken was that of all responders, and indirect standardization was used. Parity (for evermarried women only) was standardized for length of marriage and for social class; marital status was standardized for age, and social class was standardized for marital status. In no case did this procedure reveal any large difference from the crude distribution. As an example, the results of standardizing parity for length of marriage are shown in Table $\mathrm{V}$, from which it can be seen that there is very little difference between the crude and standardized distributions, or between the pipette and scrape groups.

\section{Pathology Results}

Cytopipettes were returned to the laboratory by 4994 women; included in this figure were 154 pregnant women who returned unused pipettes as they had been instructed who are classed as responders. As explained above, some of the pipette specimens were unsatisfactory in which case the test was repeated, so that the laboratory actually reported on a total of 4976 pipette specimens. Similarly, 3984 women have been classified as responders to the scrape examination (including 105 from whom no cervical scrape was taken because on attending the clinic they were found to have had a hysterectomy) but the total number of scrape specimens examined was 4289, which includes tests that had been repeated in both groups.

The results are summarized in Table VI. This shows that the proportion of unsatisfactory pipette specimens is significantly higher than that of scrape specimens. The proportion of women found to have some minor abnormality-principally inflammatory changes, trichomonas, or monilia infections-was higher among those who had had a scrape, but there was no significant difference between the two groups in the proportion of specimens that were positive for or suspicious of carcinoma in situ. The yield of 2-3 per thousand, although lower than the country as a whole, is typical of this county, and may well be a composite of initial prevalence in women who had never been tested before, and incidence in those who had had one or more previous tests. 
Janet Carruthers, J. M. G. Wilson, Jocelyn Chamberlain et al.

TABLE V

NUMBER OF CHILDREN (MARRIED RESPONDERS ONLY)

\begin{tabular}{|c|c|c|c|c|c|c|c|c|c|c|c|}
\hline & & & & \multicolumn{4}{|c|}{ Urban } & \multicolumn{4}{|c|}{ Rural } \\
\hline & & & & \multicolumn{2}{|c|}{ Pipette $(\%$} & \multicolumn{2}{|c|}{ Scrape (\%) } & \multicolumn{2}{|c|}{ Pipette (\%) } & \multicolumn{2}{|c|}{ Scrape (\%) } \\
\hline & \multicolumn{3}{|c|}{ No. of Children } & $\mathrm{Ob}$ & St & $\mathrm{Ob}$ & St & $\mathrm{Ob}$ & St & $\mathrm{Ob}$ & St \\
\hline 0 & .. & .. & .. & 17 & 17 & 13 & 14 & 17 & 15 & 13 & 13 \\
\hline 1 & .. & .. & .. & 20 & 20 & 19 & 20 & 22 & 21 & 18 & 19 \\
\hline 2 & .. & .. & .. & 33 & 34 & 39 & 38 & 34 & 35 & 35 & 34 \\
\hline 3 & .. & .. &.. & 18 & 18 & 19 & 18 & 16 & 17 & 20 & 20 \\
\hline 4 & .. & .. & .. & 7 & 6 & 6 & 6 & 7 & 8 & 9 & 9 \\
\hline $5+$ & .. & .. &.. & 5 & 5 & 4 & 4 & 4 & 4 & 5 & 5 \\
\hline \multicolumn{4}{|c|}{ Sample size } & \multicolumn{2}{|c|}{2206} & \multicolumn{2}{|c|}{2018} & \multicolumn{2}{|c|}{2163} & \multicolumn{2}{|c|}{1581} \\
\hline
\end{tabular}

$\mathrm{Ob}=$ crude distribution per cent

$\mathrm{St}=$ distribution standardized for length of marriage per cent

TABLE VI

PATHOLOGY RESULTS IN PIPETTE AND SCRAPE GROUPS

\begin{tabular}{|c|c|c|c|}
\hline Tests & Pipette & Scrape & Significance \\
\hline $\begin{array}{l}\text { Total tests } \\
\text { examined (as } \\
\text { reported by } \\
\text { laboratory) } \\
\text { Total unsatis- } \\
\text { factory tests (as } \\
\text { reported by } \\
\text { laboratory) ... }\end{array}$ & $\begin{array}{c}4976 * \\
169(3 \cdot 3)\end{array}$ & $4289 \dagger$ & $P<0.001$ \\
\hline Total responders & $4994 \ddagger$ & $3984 \&$ & \\
\hline $\begin{array}{l}\text { Minor abnormality } \\
\text { Positive or } \\
\text { suspicious } \\
\text { carcinoma in situ }\end{array}$ & $\begin{array}{l}169(3 \cdot 3) \\
13 \quad(0 \cdot 2)\end{array}$ & $\begin{array}{l}280(7 \cdot 0) \\
12(0 \cdot 3)\end{array}$ & $P<0.001$ \\
\hline
\end{tabular}

* Includes repeat pipettes

+ Includes repeat scrapes and scrapes after a pipette

¥ Includes 154 women who did not use the pipette because of pregnancy

8 Includes 105 women who did not have a smear because of a previous hysterectomy

Percentages are given in parentheses

\section{COMPARISON OF ATtitudes IN ACCEPTORS AND NON-ACCEPTORS}

The sociological survey, which set out to interview a $10 \%$ sample of women in the study stratified according to their response to the invitation for screening by either method, sought women's views on the prevention and curability of cancer. Not surprisingly, there was a marked difference in the response to interview, according to whether or nof the woman had accepted the screening invitation, $\mathcal{Q}$ with $80 \%$ of acceptors being interviewed, but less than $50 \%$ of non-acceptors. As shown in Table VII, there were valid reasons why some had noe responded and those who deliberately refuse $\vec{b}$. interview made up only $20 \%$. Nevertheless, the non-acceptors as a group are under-represented, which must be borne in mind in comparing their attitudes with those of acceptors.

It can be seen from Table VIII that the nonacceptors show a more negative attitude towards the value of presymptomatic diagnosis than the acceptors, and (Table IX) that they are less confident

TABLB VII

SOCIOLOGICAL STUDY INTERVIEW-RESPONSE RATES

\begin{tabular}{|c|c|c|c|c|}
\hline \multirow[b]{2}{*}{ Result of Interview } & \multicolumn{2}{|c|}{ Acceptors } & \multicolumn{2}{|c|}{ Non-acceptors } \\
\hline & $\begin{array}{c}\text { Pipette } \\
\%\end{array}$ & $\underset{\%}{\text { Scrape }}$ & $\begin{array}{c}\text { Pipette } \\
\%\end{array}$ & $\begin{array}{c}\text { Scrape } \\
\%\end{array}$ \\
\hline Interviewed & 80 & 79 & 48 & 49 \\
\hline $\begin{array}{l}\text { Reason for no } \\
\text { interview: } \\
\text { Left area }\end{array}$ & 5 & 4 & 18 & 20 \\
\hline Refused & 8 & 11 & 20 & 20 \\
\hline $\begin{array}{l}\text { Other (dead, no } \\
\text { contact, aged, } \\
\text { infirm) }\end{array}$ & 7 & 7 & 15 & 10 \\
\hline Sample size & 474 & 465 & 418 & 455 \\
\hline
\end{tabular}


TABLE VIII

BELIEF IN EARLY DIAGNOSIS

\begin{tabular}{|c|c|c|c|c|}
\hline \multirow{2}{*}{$\begin{array}{l}\text { Response to } \\
\text { Question }\end{array}$} & \multicolumn{2}{|c|}{ Acceptors } & \multicolumn{2}{|c|}{ Non-acceptors } \\
\hline & $\begin{array}{c}\text { Pipette } \\
\%\end{array}$ & $\begin{array}{c}\text { Scrape } \\
\%\end{array}$ & $\begin{array}{c}\text { Pipette } \\
\%\end{array}$ & $\begin{array}{c}\text { Scrape } \\
\%\end{array}$ \\
\hline $\begin{array}{l}\text { Would you want } \\
\text { to know you had a } \\
\text { disease before you } \\
\text { felt any symptoms? }\end{array}$ & & & & \\
\hline Yes, always & 77 & 81 & 55 & 60 \\
\hline Yes, sometimes .. & 12 & 9 & 13 & 10 \\
\hline No $\quad$. & 8 & 6 & 27 & 25 \\
\hline Don't know & 3 & 4 & 5 & 6 \\
\hline Sample size & 378 & 365 & 196 & 216 \\
\hline
\end{tabular}

TABLE IX

BELIEF ABOUT CURABILITY OF CERVICAL CANCER

\begin{tabular}{|c|c|c|c|c|c|}
\hline \multirow{2}{*}{\multicolumn{2}{|c|}{$\begin{array}{l}\text { Response to } \\
\text { Question }\end{array}$}} & \multicolumn{2}{|c|}{ Acceptors } & \multicolumn{2}{|c|}{ Non-acceptors } \\
\hline & & $\begin{array}{c}\text { Pipette } \\
\%\end{array}$ & $\underset{\%}{\text { Scrape }}$ & $\begin{array}{c}\text { Pipette } \\
\%\end{array}$ & $\underset{\%}{\text { Scrape }}$ \\
\hline \multicolumn{2}{|c|}{$\begin{array}{l}\text { Do you believe } \\
\text { that cervical can- } \\
\text { cer can be cured? }\end{array}$} & & & & \\
\hline Usually & . & 35 & 34 & 23 & 26 \\
\hline Sometimes & . & 60 & 63 & 68 & 66 \\
\hline Never & . & 5 & 3 & 9 & 9 \\
\hline Sample size & $\cdots$ & 377 & 360 & 190 & 215 \\
\hline
\end{tabular}

that cancer of the cervix can be cured. Additional information from the sociological study will be presented in a later paper.

\section{Discussion}

Assuming that the natural history of cancer of the cervix includes a pre-invasive phase, treatment of which halts the disease process, the relative merits of pipette and scrape as screening methods for its early detection can be considered in terms of their:

1. medical efficiency as diagnostic tests

2. economy in use of medical care resources

3. acceptability to women at risk of the disease. By balancing these three aspects some measure can be obtained of the value of each method as a possible preventive tool.
MedicAl EFFICIENCY From the diagnostic point of view, the pipette is not quite as good as the scrape method. Various estimates of its sensitivity compared with the scrape have been obtained from studies in which pipette and scrape specimens have been taken from the same women. Anderson and Gunn (1967) in Miami found a false negative rate for pipette specimens of $28 \%$, and Koch and Stakemann (1964) in Denmark found it to be $18 \%$. Husain (1970) in a London study of family planning clinic attenders and gynaecological outpatients, obtained a lower false negative rate of only $13 \%$. It seems probable that, as suggested by Anderson and Clark (1966), special training of technicians to read cytopipette specimens can keep the sensitivity up to the last two satisfactory levels. In assessing these figures it should not be forgotten that the scrape itself is not $100 \%$ sensitive, having a false negative rate possibly in the region of $20 \%$, as estimated by Yule (1973) who examined serial scrapes from the same women. The relatively high proportion of unsatisfactory pipette specimens compared with scrape specimens (borne out by our own study as well as by others) is another indication that it is not such an efficient method. Another medical consideration not related to the efficiency of each test but to the procedures involved in performing it, is the possibility of additional benefits which may derive from the physical examination of a woman done at the same time as taking the scrape specimen, but which is, of course, impossible in the case of the pipette. These almost certainly include early detection of breast cancer at the same examination, and possibly the detection of other potentially curable gynaecological conditions of which the most important is invasive carcinoma of the cervix, more likely to be found by visualization of the cervix and manual examination than by cytological methods. From the strictly medical point of view, therefore, the pipette cannot claim to equal the scrape method but in the screening context it could still be potentially useful, taking into account the other aspects.

ECONOMY Little information is available on the actual costs and use of resources of the two methods but there is no doubt that the pipette is considerably cheaper. The price of the cytopipette in our study in 1971 was $£ 0 \cdot 18$, to which must be added the administrative and computing costs in sending it out and back which amounted to about $f 0.55$, giving an overall cost of approximately $£ 0.75$. The laboratory costs of examining a pipette specimen were approximately $£ 0 \cdot 50$. Saunders and Snaith (1969b) calculated a unit cost of $£ 2 \cdot 15$ for the scrape examination, including laboratory costs, a 
figure similar to than obtained by Magee et al. (1974) who in a large survey in Cardiff estimated that the cost of the scrape test for screening was $£ 2.40$ in 1970. These figures may be extrapolated to the population of approximately 10000 women in each group in our study to give a very rough guide on the comparative screening costs of the two methods. The costs (at 1971 prices) in the whole scrape group would be between $£ 20000$ and $£ 25000$ and those in the pipette group $£ 10000$ ( $£ 7500$ in sending pipettes to the whole population and $£ 2500$ in laboratory costs for those which were used). These estimates are very approximate and do not take account of some possible savings (such as the return of unused pipettes which can be used again as they were issued in sealed transparent packs which could be returned intact); and costs (such as the higher proportion of unsatisfactory pipette specimens which need to be repeated). Also in estimating the total costs which will be incurred by a screening programme, the cost of confirmatory diagnostic procedures and treatments arising from each method need to be included and no information is available on these.

In addition, the costs to the women themselves are negligible in the case of the pipette, but may be considerable in attending for scrape examination, particularly if transport, time off work, or babysitting costs are incurred. In assessing the economic aspects, not only the financial costs, but also the availability of staff needs to be considered. While the laboratory staff costs for the two methods are similar, shortage of clinic staff may limit the number of clinics offering scrape examinations held in some areas, and also the frequency of rescreening. Thus in both financial and manpower terms it appears that there is a large margin in favour of the pipette for screening purposes.

ACCEPTABILITY The third and perhaps the most important area in which the value of the two methods may be judged is by their acceptability to women at risk of the disease, and the principal aim of our study was to measure this factor. Previous work by Davis and Jones (1966) in Maryland and by Carrow et al. (1967) in Chicago had shown response rates to the pipette as high as $80 \%$, but these studies were done on populations who were already unusually well-educated in health topics. MacGregor, Fraser, and Mann (1966) in Scotland found a much lower response rate to the pipette of only $39 \%$ and this was also the experience of Muskett, Carter, and Dodge (1966). Other studies in the USA by Naguib, Geiser, and Comstock (1968) and by Reagan and Lin (1967) found that the method was no more acceptable than the scrape method to high-risk women.

The findings of our study seem to indicate that while the pipette was more acceptable overall than the scrape, it was still apparently under-utilized by those most at risk. The convenience of the pipette test was probably a major factor in its better overall acceptability and perhaps largely accounts for the fact that the difference between pipette and scrape response in the rural area, where access to clinics was more difficult, was greater than in the urban area. Convenience was probably also a factor leading to its greater acceptance by young women, for many of whom clinic attendance would be difficult because of the ties of young children or full-time jobs. However, from the answers to questions on attitudes and beliefs, it appears that the convenience of the pipette does not persuade more of the 'non-believers' to be tested. Whether this finding would still obtain if the method were preceded or accompanied by a health education campaign is unknown.

Because of possible inaccuracy in the estimatesin of age and social class distributions in the population of women invited to be screened, our conclusions about response within age and social class groups, should be interpreted with caution. They do indicate however, that the pipette can probably persuade more middle-aged women to be screened thane would be possible by sending invitations to attend for scrape examination, but the prospects for influencing more of social classes IV and $\mathrm{V}$ to be tested are not so good. Response rates within other risk groups are unknown.

The question now arising is whether, for the purpose of population screening, the advantages of the pipette in its lower cost and its greater overall acceptability, which apparently includes middleaged women in whom the yield is likely to be high, outweigh its disadvantages in lower sensitivity. This requires an economic study in which for each method all the costs arising from offering screening to a population, incurred by the health service and by the women, are balanced against the yield of treatable disease detected by it. The balance will be influenced in favour of the pipette by its greater acceptability but against this method because of its decreased sensitivity. Included in the economic model must be the treatment costs of cancers presenting in women who screened negative (occurring more frequently in the pipette population), and in women who refused screening (occurring more frequently in the scrape population). Information on the costs of treatment is not available, and that on costs of screening is very approximate. 
Present evidence, however, is fairly clear that there is at least a limited place for the pipette in population screening. For example, it could be useful in following-up women who had refused or failed to attend for scrape examination, for re-screening women more frequently than could be done in clinics, and for supplementing screening facilities for women in rural areas. Before considering its use for any of these purposes it is, of course, essential that laboratory staff should be specially trained in the techniques involved in processing and examining pipette specimens. Whether its use should spread further than this, to replace altogether present methods of population screening by cervical scrape, will depend on the sort of economic analysis outlined above and the resources of the country in which the screening is required. This approach, assuming acceptance of the value of cervical cytology, would provide a basis for allocating resources to screening to achieve the best result with the least expenditure.

We are very grateful to Dr J. A. Heady, Dr M. J. Gardner, and Miss J. Cooper for statistical advice in the planning of the study; to Dr T. McL. Galloway, then the Medical Officer of Health in West Sussex, and his staff for providing us with facilities for this survey; to the staff of the West Sussex County Council Computer Unit for adapting their systems for the study; to the staff of the cytology laboratory at St Stephen's who examined the specimens; to the assistants and interviewers for the sociological study; and to Professor J. N. Morris of the London School of Hygiene and Tropical Medicine, for his continued support, advice, and encouragement. The study was supported by a grant from the Department of Health and Social Security.

Requests for reprints: Dr Jocelyn Chamberlain, Department of Community Medicine, University College Hospital Medical School, 115 Gower Street, London WC1.

\section{REFERENCES}

Aitren-Swan, J. and Baird, D. (1966). Cancer of the uterine cervix in Aberdeenshire, aetiological aspects. Brit. J Cancer, $20,642$.

Allman, S. T., Chamberlain, J., and Harman, P. (1974). The national cervical cytology recall system: report of a pilot study. Hlth Trends, 6, 39.

Anderson, A. F. and Clark, F. R. (1966). Vaginal irrigation pipette smear. Lancet, 1, 479.

Anderson, W. A. D. and Gunn, S. A. (1966). A critical evaluation of the vaginal irrigation kit as a screening method for the detection of cancer of the cervix, Acta cytol. (Philad.), 10, 149. and - (1967). Cancer of the cervix: further studies of the patient-obtained vaginal irrigation smear. Cancer, 17, 102.

BoYd, J. T. and Doll, R. (1964). A study of the aetiology of carcinoma of the cervix uteri. Brit. J. Cancer, 18, 419.

BresLow, L. and Hochstim, J. R. (1964). Sociocultural aspects of cervical cytology in Alameda County, California. Publ. Hlth Rep. (Wash.), 79, 107.

Carrow, L. A., Hilker, R. J., Elesh, R. E., and EgGum, P. R. (1967). Evaluation of the vaginal irrigation smear technique. Amer. J. Obstet. Gynec., 97, 821.

DAvis, H. J. and Jones, H. W. (1966). Population screening for cancer of the cervix with irrigation smears. Amer. J. Obstet. Gynec., 96, 605.

- and KURZ, L. (1962). Detection of pre-invasive cancer by the irrigation smear technique. Dan. med. Bull, 9, 121.

Fink, R., Shapiro, S., and Lewison, J. (1968). The reluctant participant in a breast cancer screening program. Publ. Hlth Rep. (Wash.), 83, 479.

Husain, O. A. N. (1970). The irrigation smear. Amer. J Obstet. Gynec., 106, 138.

Kauppinen, M. A., Kauraniemi, T., Keli, T., and? VoIPIo, N. (1970). Response to the written invitation in a gynecological mass screening by cytology arrange in Helsinki in 1966. Acta obstet. gynec. scand., 49 Suppl. 7.

KEGELES, S. S. (1967). Attitudes and behaviour of the public regarding cervical cytology: current findings and new directions for research. J. chron. Dis., 20,911.

KINLEN, L. J. and Doll, R. (1973). Trends in mortality from cancer of the uterus in Canada and in England and Wales. Brit. J. prev. soc. Med., 27, 146.

Koch, F. and StakemanN, G. (1962). The irrigation smear. Dan. med. Bull., 9, 127.

— and - (1964). A population screening for carcinoma of the uterus with the irrigation smear technique. Dan. med. Bull., 11, 209.

MacGregor, J. E., Fraser, M. E., and ManN, E. M. F. (1966). The cytopipette in the diagnosis of early cervical carcinoma. Lancet, 1, 252.

Magee, C. C., Edwards, J. R., Connies-Laing, P., and Richards, M. (1974). Report on Costing Cervical Cytology. University College, Cardiff.

MuSketT, J. M., CARTER, A. K., and Dodge, O. G. (1966). Detection of cervical cancer by irrigation smear and cervical scraping. Brit. med. J., 2, 341.

NAGUib, S. M., Geiser, P. B., and Comstock, G. W. (1968). Response to a program of screening for cervical cancer. Publ. Hlth Rep., 83, 990.

Reagan, J. H. and LiN, F. (1967). An evaluation of the vaginal irrigation technique in the detection of uterine cancer. Acta cytol. (Philad.), 11, 374. 
RotKIN, I. D. (1962). Relation of adolescent coitus to cervical cancer risk. J. Amer. med. Ass., 179, 486.

Sansom, C. D., Wakefield, J., and Yule, R. (1970). Cervical cytology in the Manchester area: changing patterns of response. Med. Offr., 123, 357.

SAUNDERS, J. and SNATth, A. H. (1969a). Cervical cytology consent rate. Lancet, 2, 207.

and (1969b). Results of a computer-assisted cervical cytology programme. 13th Scientific Meeting of the Society for Social Medicine, Glasgow. (unpublished).
TerRis, M. and Oalmann, M. C. (1960). Carcinoma of the cervix: an epidemiologic study. J. Amer. Med. Ass., 174, 1847.

Vuori, H., Rimpela, M., and Gronroos, M. (1972) The problem of non participation. Int. J. Hlth Educ., $15,22$.

Wakefield, J. and Sansom, C. D. (1966). Profile of a population of women who have undergone a cervical smear examination. Med. Offr., 116, 145.

YULE, R. (1973). The prevention of cancer of the cervix by cytological screening of the population. In Cancer of the Uterine Cervix, edited by E. D. Easson, p. 11 Saunders, London. 